\title{
Primary school education resources on conservation in New Zealand over-emphasise killing of non-native mammals
}

\author{
Michael C. Morris* \\ Royal Agricultural University, Auckland, New Zealand \\ ${ }^{*}$ Corresponding author. E-mail: Michael.morris@rau.ac.uk
}

(Received 03 September 2020; revised 23 July 2021; accepted 01 September 2021; first published online 16 December 2021)

\begin{abstract}
Guidelines for sustainability linked to the government-approved National Curriculum for education in New Zealand emphasise values of empathy and respect for all life. These instruct educators to discuss different values around sustainability and conservation.

I reviewed educational resources published or endorsed by government agencies to determine compliance with these sustainability Guidelines. The resources reviewed promote the view that non-native mammals should be killed. Some resources go further in giving instructions to children on how to do this, and how to source kill traps. Children are provided with material designed to engender dislike towards non-native mammals, particularly possums. Resources conflate issues of conservation by tying it in with protection of tourism, ornamental plants and primary industries.

This encouragement of killing in environmental educational resources appears unique to New Zealand. It is discussed in light of increasing evidence that performing or witnessing animal abuse is a causal factor for future violence towards human and non-human animals.
\end{abstract}

Keywords: conservation; pest control; possums; New Zealand

\section{Introduction}

New Zealand is a biodiversity hot spot, meaning that it combines a diverse range of endemic flora with a high proportion of threatened and endangered species (Myers et al., 2000). The New Zealand bird (Scofield \& Stephenson, 2013) and invertebrate (Buckley et al., 2015) fauna are characterised by unique species assemblages and high degrees of endemicity.

New Zealand's unique biodiversity is threatened from several fronts. Logging for timber in the 19th century had some effect, but much of the destruction of terrestrial habitats, especially of wetlands and lowland kahikatea forests, has been due to land clearance for animal agriculture (Joy, 2015; Park, 1995). Present day animal agriculture is responsible for further degradation of habitat, particularly fresh water ecosystems, and the endangerment of native fresh water fish (Joy, 2015; Joy et al., 2019; Ministry for the Environment and Statistics NZ, 2019).

Another factor in biodiversity decline is introduced animals, particularly mammals, though introduced trout also contribute to destruction of fresh water species (McIntosh et al., 2010; Steer, 2015). New Zealand plants and animals evolved in the absence of native mammalian predators or browsers. New Zealand plants and birds supposedly have no defence mechanisms against mammals that were later brought into the country by human introductions (Antonelli et al., 2011; King, 2005). 
New Zealand conservation policy focusses strongly on control of introduced mammals, and less on other restoration activities, such as reforestation, regulation of destructive primary industries, or not breeding introduced fish such as trout. For example, the Freshwater Fisheries Regulations (1983) allow the taking of indigenous fish for food, whereas invasive trout species are provided special protection in Part 5A of the Conservation Act (1987).

The Department of Conservation (DoC) is the government body with the mandate to preserve biodiversity. It has followed a policy of controlling non-native mammal species since 1951 (Cowan, 1990).

This policy was strengthened in 2016 with the establishment of the Predator Free New Zealand (PFNZ) Trust. This was started as a limited liability company, not a government agency (Morris, 2020). The trust now has government backing, and is made up of a loose confederation of government agencies, charities and private companies.

PFNZ has the aim of eliminating predators by 2050. It concentrates its efforts specifically on what is calls the 'Big Three' predators; possums (Trichosurus vulpecula), ship rats (Rattus rattus) and stoats (Mustela erminea).

The policy of total eradication has its critics from an environmental and ethical point of view. A new ethic of compassionate conservation for example condemns conservation strategies that centre around a macho narrative of toughness and killing (Steer, 2015). Under this ethos, individual human and non-human animals should be provided with the same ethical consideration as species and ecosystems (DuBois et al., 2017; Wallach et al., 2020).

Greater realisations that the natural environment in New Zealand is in a state of constant flux through continuous natural disturbances (Wyse et al., 2018) has also brought into question the prevailing view that the aim of conservation should be to preserve some pre-settlement ideal habitat, which may not have even existed (Ellis, 2015).

Some environmental advocacy groups such as the Jane Goodall Institute have questioned the appropriateness of encouraging children to trap rats and other animals, due to concerns over such behaviour teaching them to become more violent adults (Bekoff, 2020).

Other conservationists consider that while some local areas of predator control may be warranted, conservation policy needs to move away from an emphasis on trapping, poisoning and shooting as a primary means of control (Linklater \& Steer 2018). Promising areas of technology such as gene drives and contraceptive control need to be explored (Morris, 2020). Other conservationists advocate learning to live with introduced species, and exploring alternative means of conserving our environment, which may include addressing destructive activities by humans (Linklater \& Steer, 2018; Wallach et al., 2020).

The current statutory documents for education and sustainability in primary schools are in the New Zealand Curriculum, published by the Ministry of Education (updated December 2017), and available online. The Curriculum emphasises a number of values. These include critical thinking, equity and fairness, community participation for the common good, integrity, acting ethically, and respect for others.

The Ministry of Education have published a more recent curriculum resource, Education for Sustainability (updated July 2020), also available online (https://nzcurriculum.tki.org.nz/ Curriculum-resources/Education-for-sustainability). It contains additional guidelines and curriculum links specifically related to sustainability education.

Education for Sustainability further expands and defines the values provided in the Curriculum. Values include equity, which is defined as 'respect for all life, social justice, intergenerational equity, finite resources'. Students are encouraged to engage with opportunities to:

- learn about their own values and those of others

- explore with empathy the values of others

- critically analyse values and the actions based on them

- discuss disagreements that arise from differences in values and negotiate solutions

- make ethical decisions and act on them 
It is therefore disconcerting to note the extent to which the values in the Curriculum and Education for Sustainability are ignored or sidelined in primary schools. School children have been encouraged to hunt, trap and drown possums, and then to humiliate their corpses (Morris, 2020; Tulloch, 2018).

Most accounts of this occurring are from rural schools, though an Auckland primary school has also created controversy in this area with one of its teachers rhetorically asking "Which are the animals that you want to kill the MOST?" (VICE, 2018). I can also report anecdotally that one of my own urban 9-year-old students recounted to me a teacher's story about the 'evil' possums.

There is not enough evidence to state whether this is an example of a rural vs urban divide. Engendering lack of empathy towards non-native mammals appears to be ubiquitous among New Zealand schools. This is in line with the PFNZ narrative of eliminating 'pests' and 'predators'. A survey of primary school teaching resources would be a useful way of determining to what extent the PFNZ narrative is embedded in environmental education in New Zealand.

\section{A Survey of Educational Resources}

To check to what extent resources reflect stated policy, I surveyed recent conservation educational resources for primary school students (age 5-12), published by government agencies, or by organisations openly endorsed by government agencies, through links from government agency websites.

I started my search by typing 'environmental education resources NZ' into Google, then following links. This revealed the following government-published or government-endorsed resources on conservation for primary schools.

\section{Department of Conservation (DoC)}

The DoC has its own site for education (https://www.doc.govt.nz/education), which links to a number of teachers' resources.

Investigating introduced predators in your green space (DoC, 2018a) is a 32-page booklet that provides information to students about introduced predators and suggestions on how to monitor for their presence. One of the photographs shows primary aged children with a kill trap, and the caption 'students setting a trap'.

The resource makes blanket predictions about the negative effects of predators if they are not eradicated, which do not take into account the complexities of ecological interactions (Linklater \& Steer, 2018), or the role of human activities in environmental damage.

DoC (2018a) states that 'possums also eat eggs and chicks of endemic birds such as the kereru and kokako'. This is a controversial statement given that only a few instances of possums eating birds have ever been documented (Morris, 2020), whereas 50 years of stomach content analysis has not revealed any remnants of birds, bird eggs or endangered invertebrates (Sweetapple et al., 2013 and references therein).

One reason this resource gives for controlling predators is that $72 \%$ of New Zealand native fish are endangered. But none of the introduced mammals are responsible for this. Fresh water fish are threatened predominantly by land runoff (Joy, 2015; Joy et al., 2019), introduced fish such as trout (McIntosh et al., 2010; Steer, 2015), and dams and other barriers (Jellyman \& Harding, 2012). Interestingly, this is pointed out in another DoC website for the wider public, where whitebait fishing is also listed as a cause of freshwater fish decline (DoC, undated).

Animal welfare is given brief mention by DoC (2018a), in a note to teachers saying they should 'encourage our children to think about the animals' life that has been taken.' It mentions the way many indigenous cultures show respect to the animals killed, but it is taken for granted that the animals have to be killed, and that it is appropriate for children to kill them. 
A second booklet, Tools for Environmental Action (DoC, 2017), is more holistic in that 'Pest control' is listed as only one of the 'tools'. Human activities such as habitat destruction and the impact of climate change are mentioned. The booklet does however contain the same photograph of children setting traps.

The booklet Conservation Dogs Programme: school visit information and supporting resources for teachers (DoC, 2018b) is ostensibly about arranging school visits for the DoC conservation dogs, which have roles in identifying and 'destroying' animal 'pests', including mice, rats, possums, feral cats, mustelids, rabbits, wallabies and 'plague skinks', as well as assisting hunters to shoot feral goats, deer and pigs.

There are links to instructions on how to set kill-traps. A lesson plan and learning guide leads student enquiries towards discussion of trapping as a means of 'planning for action to make a local environment predator-free'.

Possum picnic (Law and McConnell, undated), is linked from the DoC and PFNZ education websites (qv). It is an interactive action game where students play 'trees', 'possums' and 'hunters'. The latter 'shoot' the 'possums' by throwing sponge balls. After the game is run a few times with variations, 'poison' is introduced, which kills the 'possum' if they touch it.

Encouraging shooting and poisoning as some sort of game trivialises the suffering that these activities cause. Once more, the text states that possums directly eat native birds and their eggs. DoC step outside their conservation mandate, justifying killing possums because they threaten the animal agriculture industry, and because they are a 'nuisance' in suburban gardens.

The 'habitat heroes' link from the DoC education website (https://www.doc.govt.nz/getinvolved/conservation-education/national-programmes/habitat-heroes), describes school activities that encourage children to 'think about how they can make a difference'. Eleven schools are mentioned, ten of which involve replanting, clearing weeds or rubbish removal. The first school listed however links to a project by Haumoana School from 2017, which involved 'taking action to bring back native birds to their school through tracking, trapping and planting.'

\section{Ministry of Education}

The School Journal, a resource for teachers and students, has been published by the Ministry of Education and its predecessors since 1907 (Ministry of Culture and Heritage, 2018). Three articles from this journal favour killing.

The School Journal article Too many possums (Boyle, 2010) pre-dates the PFNZ campaign. It belongs to a time when the possum was still considered the most significant 'pest' species in New Zealand (Montague, 2000). It is linked from the DoC education website, showing that it is still considered relevant by a government department.

The resource warns teachers that children may find it hard to think of possums as 'pests' when they are 'cute and cuddly'. The subtext is that the children's natural empathy to possums must be reconditioned in this case. This is part of the 'cute, but ...' narrative common in discourse around this hated animal (Potts, 2009).

There is no exploration of values or options. In the teachers' notes, the only negative given for using traps and poisons is financial cost. Animal welfare considerations are not mentioned.

The article The Possum Problem (Knox, 2017) provides a brief history of how settlers brought possums into New Zealand for fur. It is worded in a way that exonerates the settlers, who can plead ignorance, but puts the blame on the possums. The only control methods listed are shooting, trapping and poisoning, with no debate on animal welfare or alternatives such as gene drive, contraceptives or repellents. Accidental death of non-target organisms is mentioned as a risk from poisoning, but this is considered acceptable.

Possums are again described as killing native birds directly. The article suggests readers 'buy possum traps' for use at home. 
Designed for Good (Cleaver, 2017), describes the steps taken to design a trap. It continues with statements that possums prey on birds' eggs. The objectives of PFNZ are praised, and the development of better killing traps are described as an 'exciting development in pest control'.

\section{World wildlife fund New Zealand (WWF NZ)}

The New Zealand branch of this international NGO is a co-author of Can we make New Zealand Pest Free (Zealandia, Predator Free NZ \& World Wildlife Fund NZ 2019). This is linked from the DoC education site. The other authors are PFNZ, and Zealandia. The latter is a predator-free sanctuary in Wellington, which is known to harbour a hatred of possums (Potts, 2009).

This resource provides a comprehensive series of lessons that encourage children to buy traps from PFNZ and use these to trap non-native mammals in their school. It encourages teachers to act as recruiters for PFNZ, stating that it is important for them to persuade children about the 'reasons we need to make Aotearoa predator free and the crucial role children play in this vision'.

This resource does pay lip service to a more moderate viewpoint when it suggests teachers tell the children the non-natives are not 'bad' animals, just in the wrong place.

\section{Forest and bird}

This influential conservation charity runs a youth division, the Kiwi Conservation Club, which is linked from the DoC education site. This includes a series of online magazines, Wild Things. One article from this magazine (Forest \& Bird, 2019) includes a series of drawings on how to build a kill trap for rats. The concept came from PFNZ, and the photographs from DoC.

\section{Predator Free New Zealand (PFNZ)}

This organisation is linked from the DoC education site. It gives grants for 'predator free schools' to enable schools to trap in their own campus. Like DoC (2018a), PFNZ repeat the statement that $72 \%$ of fresh water fish are endangered, implying that this is due to non-native mammals.

Included on the page is an embedded You Tube video (https://youtu.be/eihJ8DeDIOE). This starts with an adult male humiliating a rat corpse, while saying 'You didn't see that one coming, did you?' It demonstrates to children how to set kill traps in their campus or back yard. Some lip service is paid to animal welfare with an injunction that we must show 'respect for all living animals' and be 'humane'.

Teachers are linked to a series of resources plus an advertisement for kill traps on a new page. The first of these is a lesson plan, published by PFNZ, which includes suggestions on applying for funding for trapping. It suggests that children run a competition to see who catches the most, and establish a school-wide trapping plan.

\section{National Pest Control Agency Inc.}

This is run by a consortium of central and local government agencies. It produces a teachers' booklet on possum control for use in primary schools (Wedge, undated a), and a student work book (Wedge, undated b). These resources both state that possums feed on birds' eggs and chicks. The favoured control methods described are poisoning, shooting, trapping, and using dogs. Animal welfare concerns over poisoning are not addressed, even in the suggested activity where students are encouraged to debate the pros and cons of poisoning. 
The student booklet states that possums carry the disease bovine tuberculosis $(\mathrm{Tb})$, which can make people 'very sick', even though pasteurisation of milk means that human infection from bovine $\mathrm{Tb}$ is extremely rare. Bovine $\mathrm{Tb}$ is on the decline in New Zealand cattle (Gormley et al., 2018).

\section{Te Papa Tongarewa - National Museum of New Zealand}

This Crown Entity was established by Act of Parliament (Museum of New Zealand Te Papa Tongarewa Act 1992). Its functions under this Act are to display and exhibit items of art and items relating to history and the natural environment. This includes education relating to these matters.

In July 2020, Te Papa featured a display for primary school students about introduced animals entitled 'What's wiping out our native wildlife.' The entire display was set up to engender fear and dislike. It is still on display in September 2021.

Some examples of ways in which non-native animals were turned into a 'foe' (Holm, 2015) are as follows:

- A display of a video showing a girl of around 10 years old setting kill traps and then disposing of a possum carcase after picking him/her up by the tail.

- A display entitled 'who is on the prowl in your backyard after dark'. The display featured stuffed animals set in poses showing them stalking or killing wildlife. A stuffed possum is shown sneaking up on tui eggs.

- Children are encouraged to look at a display of a New Zealand-made resettable rat trap and use it as inspiration to 'design the rat trap of the future'. Pencils, paper and a pin board are provided.

\section{The Science Learning Hub}

This is a government-funded organisation with the aim to promote science education. It is linked from the DoC education website. All the resources can be found on the Science Learning Hub website (https://www.sciencelearn.org.nz).

The slide show Pest detectives includes commentary by DoC staff showing teachers how to run a pest investigation. It introduces DoC resources, including those described earlier (DoC, 2017, 2018a, 2018b). It is broader in scope than some of the DoC material, covering invasive plants as well as fishes introduced for game.

The section on ethics mentions the kiore rat (Rattus exulans), which is believed to have been brought to New Zealand with the original Maori settlers (King, 2005). It describes this rat as a taonga species and therefore one that has to be respected under the Treaty of Waitangi, but there is no mention of animal cruelty or any consideration of other non-native mammals.

The authors suggest that teachers 'be prepared to discuss, debate and make changes' when discussing ethics, but they are not more specific. Biological control of possums is mentioned as an alternative to trapping and poisons.

The resource Ethics in bird conservation provides a broad ethical discussion based around the question 'Should money and effort be spent trying to save native birds such as the kākāpō?' The resource starts with an introduction to ethical discourse, and lists a number of ethical questions to discuss. These include whether some species are more important than others, and how should we decide.

Ethics in bird conservation suggests a range of different conservation approaches, such as translocation, not only predator control. It encourages children to take different points of view, including that of a mammalian predator. As such it takes a much more open approach to environmental 
ethics than resources described so far, and gives effect to the principles in Education for Sustainability (qv).

The Science Learning Hub has a series of resources around ethical issues in science, including Ethics in conservation science, and ethics of xenotransplantation. All of these explore the issues broadly, and include a consideration of the animals' point of view.

\section{Conclusion}

The resources described are published or displayed by four government agencies, three conservation NGOs and one government funded education organisation (Science Learning Hub).

All of the government agencies and conservation NGOs, even the Ministry of Education resources, encourage children to kill non-native mammals, show them how to set traps, and emphasise to teachers how they need to impress on children the importance of eradicating 'pests'.

All these organisations promote trapping or poisoning to eliminate non-native mammals as the only way to control them, and therefore to preserve biodiversity. No consideration is given to alternatives, such as changing human activities, non-lethal contraceptive or gene drive techniques, more localised and targeted pest control, or translocation techniques such as Operation Nest Egg (Linklater and Steer, 2018; Morris, 2020).

The only organisation that considers alternatives, takes a more nuanced ethical approach and allows children to imagine themselves in the place of the animals is the Science Learning Hub. This could be because its mandate is education and not conservation. The only resource produced by this organisation that does emphasise killing was one in which DoC had a major input.

New Zealand is not unique in presenting discourses of 'war' and 'invasion' to engender support for eradication policies (Lawson, 2015). It is also not unique in advocating for better classroom education to ensure public support for these policies (eg. Waliczek et al., 2018). Other countries kill unwanted animals by government mandate, such as the badger cull in the United Kingdom. However, pest operatives carrying out the killing are licenced adults (McCulloch \& Reiss, 2017). New Zealand appears unique in encouraging children to kill animals, as part of a government recruitment strategy.

This can be seen in three of the Doc resources (DoC 2017, 2018a, 2018b), plus the DoC 'habitat heroes' description. It is also a part of a School Journal publication (Knox, 2017). Among conservation NGOs, the resource by Zealandia, Predator Free NZ \& World Wildlife Fund NZ (2019) and Forest and Bird (2019) exhort children to buy and set traps. The entire PFNZ education website (linked from DoC) is based around sales of their traps and instructions on their use.

These resources actively encourage killing. They can be contrasted with the official Curriculum, supplemented by Education for Sustainability. These emphasise exploring values, ethics and empathy. Some of the Learning Connection resources on ethics emphasise this approach.

The de facto educational policy and resources by government agencies therefore appear to be at odds with those mandated by the Ministry of Education. This is problematic given that there is a well-established link between children abusing animals and becoming abusers of human and nonhuman animals as adults (Flynn 2011; Randour et al., 2019).

There is increasing evidence that this association is not merely a link but a causal relationship. Baldry (2003) found that children who merely witnessed animal abuse were more likely to become animal abusers, even when the children had not been abused themselves. Seeing peers abuse animals was the strongest predictor for later animal abuse, followed by seeing parents abuse animals. Randour et al. (2019) summarise studies showing how the ages at which children witness animal abuse is correlated with the age at which they become animal abusers themselves. There was a stronger relationship between witnessing animal abuse and becoming an animal abuser if the abuse was witnessed more than once, or if the individual abusing animals in front of the child was a friend, relative, parent or sibling (Gullone 2014; Randour et al., 2019). 
Gullone (2014) considers that this causal relationship can be explained in terms of vicarious learning theory in which observation of behaviour by a trusted person is more likely to lead to performance of the behaviour. This would include teachers, who have a duty to model good behaviour.

Children's attitudes to animals is another predictor of later animal abuse. Adolescents who hold a world view of intrinsic human superiority, one that is implicit in the government teaching resources reviewed above, are more likely to be animal abusers (Begue, 2020). Conversely, a study in Scotland found that an education programme teaching children about animal minds led to improved knowledge about the sentience of animals, and their ability to feel emotions. This is linked to showing more understanding and empathy to animals (Hawkins et al., 2017).

A direct study showing a causal relationship between exposure to animal abuse in children and later abuse of humans has not been conducted. However, since exposure to animal abuse and dismissive attitudes towards animals can lead to animal abuse (Baldry, 2003; Gullone, 2014; Randour et al., 2019), and since animal abuse is a predictor of human abuse (Flynn, 2011, Randour et al., 2019), a link can be reasonably inferred.

Among adults, evidence for a causal link between abusing animals and humans is stronger. A study from rural US communities found that communities dominated by workers from slaughterhouses (another socially sanctioned industry involving violence towards animals), had higher levels of violent crime towards humans compared with those based on similar low-paid blue-collar industries. The authors conclude that it is the desensitising experience of the work that leads to the violence, and not that slaughterhouse workers choose that type of work because they are intrinsically more violent (Fitzgerald et al., 2009).

The studies above suggest that an education system based on glorification of killing and dismissing animal interests can lead to an increasing incidence of abuse to animals and humans.

The New Zealand Curriculum emphasise values of critical thinking, equity and fairness, community participation for the common good, integrity and acting ethically, and respect for others. Recommendations on how to teach these values are expanded Education for Sustainability guidelines and in teaching resources such as the Science Learning Hub ethics resources, the principals of the Jane Goodall foundation (Bekoff, 2020) and the philosophy of compassionate conservation (Wallach et al., 2020). They are largely absent from the resources published by government agencies and NGOs endorsed by government agencies and described above.

The disproportionate influence of DoC and PFNZ on the present de facto education strategy can be reasonably inferred. The Ministry of Education appears to be taking only a minor role. A whole of government approach that encompasses the Ministries of Health, Education and the Environment as well as the Children's Commissioner, would better ensure that children's long-term health and education are better protected, and that conservation education resources take a broader view, that better reflects stated educational policy.

Acknowledgements. None.

Funding. This research received no specific grant from any funding agency, commercial, or not-for-profit sectors.

Conflict of interest. None.

\section{References}

Antonelli, A., Humphrey, A.M., Lee, W.G., \& Linder, H.P. (2011). Absence of mammals and the evolution of New Zealand grasses. Proceedings of the Royal Society B, 278, 695-701.

Baldry, A.C. (2003). Animal abuse and exposure to interparental violence in Italian youth. Journal of Interpersonal Violence, $18,258-281$.

Begue, L. (2020). Explaining animal abuse among adolescents: The role of speciesism. Journal of Interpersonal Violence. https://doi.org/10.1177/0886260520959643

Bekoff, M. (2020). Jane Goodall Says Don't Use 1080, Jan Wright Says Use More. Psychology Today blog. 
Boyle, K. (2010). Too many possums. School Journal, Ministry of Education.

Buckley, T.R., Krosch, M., \& Leschen, R.A.B. (2015). Evolution of New Zealand insects: Summary and prospectus for future research. Austral Entomology, 54, 1-27.

Cleaver, P (2017). Designed for good. School Journal, May 2017.

Cowan, P.E. (1990). Brushtail possum. In C. King (Ed.), The handbook of New Zealand mammals (pp. 68-98). Oxford and New York: Oxford University Press.

DoC. (2017). Tools for environmental action. Wellington: DoC.

DoC. (2018a). Investigating introduced predators in your green space. Wellington: DoC.

DoC. (2018b). Conservation Dogs Programme: School Visit information and supporting resources for teachers. Wellington: DoC.

DoC. (undated). Why whitebait are in decline. https://www.doc.govt.nz/nature/native-animals/freshwater-fish/whitebaitmigratory-galaxiids/you-can-help/

Dubois, S., Fenwick, N., Ryan, E.A., Baker, L., Baker, S.E., Beausoleil, N.G. et al. (2017). International consensus principles for ethical wildlife control. Conservation Biology, 31, 753-760.

Ellis, E.C. (2015). Ecology in an anthropogenic biosphere. Ecological Monographs, 85, 287-331.

Fitzgerald, A.J., Kalof, L., \& Dietz, T. (2009). Slaughterhouses and increased crime rates: An empirical analysis of the spillover from "The Jungle" into the surrounding community. Organisation and Environment, 22, 158-184.

Flynn, C.P. (2011). Examining the links between animal abuse and human violence. Crime, Law and Social Change, 55, 453468.

Forest and Bird. (2019). Build a back yard trapping tunnel. Wild Things Magazine 142, https://kcc.org.nz/portfolio/build-abackyard-trapping-tunnel

Gormley, A.M., Anderson, D.P., \& Nugent, G. (2018). Cost-based optimization of the stopping threshold for local disease surveillance during progressive eradication of tuberculosis from New Zealand wildlife. Transboundary and Emerging Diseases, 65, 186-196.

Gullone, E. (2014). Risk factors for the development of animal cruelty. Journal of Animal Ethics, 4, 61-79.

Hawkins, R.D., Williams, J.M., \& Scottish Society for the Prevention of Cruelty to Animals. (2017). Assessing Effectiveness of a Nonhuman Animal Welfare Education Program for Primary School Children. Journal of Applied Animal Welfare Science, 20, 240-256.

Holm, N. (2015). Consider the possum: Foes, anti-animals, and colonists in paradise. Animal Studies Journal, 4, 32-56.

Jellyman, P.G., \& Harding, J.S. (2012). The role of dams in altering freshwater fish communities in New Zealand. New Zealand Journal of Marine and Freshwater Research, 46, 475-489.

Joy, M. (2015). Polluted inheritance. New Zealand's fresh water crisis. Wellington: Bridget Williams Books.

Joy, M.K., Foote, K.J., McNie, P., \& Piria, M. (2019). Decline in New Zealand's freshwater fish fauna: Effect of land use. Marine and Freshwater Research, 70, 114-124.

King, C. (2005). The handbook of New Zealand mammals, second edition. Melbourne: Oxford University Press.

Knox, J. (2017). The possum problem. School Journal, August 2017.

Law, B., \& McConnell, B. (undated) Possum picnic. https://www.doc.govt.nz/get-involved/conservation-education/resources/ possum-picnic/

Lawson, B.M.H. (2017). The war of the roses: Demilitarizing invasion biology. Frontiers in Ecology and the Environment, 3 , 495-500.

Linklater, W., \& Steer, J. (2018). Predator free 2050: A flawed conservation policy displaces higher priorities and better, evidence-based alternatives. Conservation Letters. https://doi.org/10.1111/conl.12593

McCulloch, S.P., \& Reiss, M.J. (2017). Bovine tuberculosis and badger culling in Britain: Science, policy and politics. Journal of Agricultural and Environmental Ethics, 30, 469-484.

McIntosh, A.R., McHugh, P.A., Dunn, N.R., Goodman, J.W., Howard, S.W., Jellyman, P.G. et al. (2010). The impact of trout on Galaxiid fishes in New Zealand. New Zealand Journal of Ecology, 34, 195-206.

Ministry for Culture and Heritage. (2018). First School Journal Published, 9 May 1907, https://nzhistory.govt.nz/first-schooljournal-published.

Ministry for the Environment and Statistics New Zealand. (2019). Environment Aotearoa 2019. Wellington: Ministry for the Environment and Statistics New Zealand.

Montague, T.L. (2000). The brushtail possum: Biology, impact and management of an introduced marsupial. Lincoln: Manaaki Whenua Press.

Morris, M.C. (2020). Predator Free New Zealand and the 'war' on pests. Is it a just war? Journal of Agricultural and Environmental Ethics, 33, 93-110. https://doi.org/10.1007/s10806-019-09815-x

Myers, N., Mittermeier, R.A., Mittermeier, C.G., da Fonseca, G.A.B., \& Kent, J. (2000). Biodiversity hotspots for conservation priorities. Nature, 403, 853-858.

Park, G. (1995). Ngā Uruora: Ecology and history in a New Zealand landscape. Wellington: Victoria University Press.

Potts, A. (2009). Kiwis against possums; a critical analysis of anti-possum rhetoric in Aotearoa New Zealand. Society and Animals, 17, 1-20. 
Randour, M.L., Smith-Blackmore, M., Blaney, N., DeSousa, D., \& Guyony, A-A. (2019). Animal abuse as a type of trauma: Lessons for human and animal service professionals. Trauma Violence and Abuse, 1-12. https://doi.org/10.1177/ 1524838019843197

Scofield, P., \& Stephenson, B. (2013). Birds of New Zealand: A photographic guide. Auckland: Auckland University Press.

Steer, J. (2015). The reconciliation of introduced species in New Zealand: Understandings from three 'exceptional' case studies. PhD thesis, University of Auckland.

Sweetapple, P. J., Ruscoe, W. A., \& Nugent, G. (2013). Dietary changes in response to population reduction in the possum Trichosurus vulpecula in New Zealand. Wildife Research, 40, 561-569.

Tulloch, L. (2018, January). Teaching our kids to kill in the name of conservation. Stuff. Retrieved January 22, 2018 from https://www.stuff.co.nz/environment/100695495/teaching-our-kids-to-kill-in-name-of-conservation

VICE (2018). New Zealand's children are setting traps to kill invasive mammals. https://www.facebook.com/watch/?v= 180602895912487

Waliczek, T.M., Parsley, K.M., Williamson, P.S., \& Oxley, F.M. (2018). Curricula Influence College Student Knowledge and Attitudes Regarding Invasive Species. HortTechnology, 28, 548-556.

Wallach, A.D., Batavia, C., Bekoff, M., Alexander, S., Baker, L. et al (2020). Recognising animal personhood in compassionate conservation. Conservation Biology. doi: 10.1111/cobi.1349.

Wedge, G. (undated a). The how and why of possum control: Teachers' booklet. Wellington: National Pest Control Agency.

Wedge, G. (undated b). The how and why of possum control. Wellington: National Pest Control Agency.

Wyse, S.V., Wilmshurst, J.M., Burns, B.R., \& Perry, G.L.W. (2018). New Zealand forest dynamics: A review of past and present vegetation responses to disturbance, and development of conceptual forest models. New Zealand Journal of Ecology, 42, 87-106.

Zealandia, Predator Free NZ \& World Wildlife Fund NZ (2019). Inquiry: Can we make New Zealand pest free. Wellington: Zealandia.

Michael Morris gained a PhD in zoology from the University of Auckland. He has taught environmental science and biology at university level in New Zealand, China and Japan. Michael has also been a research scientist, a government policy adviser, an environmental advocate and a political candidate. He is presently teaching science to primary aged children at an afterschool centre.

Cite this article: Morris, M.C. (2022). Primary school education resources on conservation in New Zealand over-emphasise killing of non-native mammals. Australian Journal of Environmental Education 38, 168-177. https://doi.org/10.1017/ aee.2021.19 